\title{
DIRECT MEASUREMENT OF PRESENT-DAY TECTONIC MOVEMENT AND ASSOCIATED RADON FLUX IN POSTOJNA CAVE, SLOVENIA
}

\author{
Stanka Š́bela ${ }^{1}$, Janja Vaupotič2, Blahoslav KošŤák ${ }^{3}$, And Josef Stemberk ${ }^{3}$
}

\begin{abstract}
Micro-tectonic deformations have been monitored continuously in 3D in Postojna Cave, Slovenia with TM 71 extensometers since 2004. Two instruments, $260 \mathrm{~m}$ apart, were installed on the Dinaric oriented (NW-SE) fault zone that is situated about $1,000 \mathrm{~m}$ north of the inner zone of the regionally important Predjama Fault. Monitoring on both instruments has shown small tectonic movements (i.e., a general dextral horizontal movement of $0.05 \mathrm{~mm}$ in four years [Postojna 1] and extension of $0.03 \mathrm{~mm}$ in four years [Postojna 2]). Between the longer or shorter calm periods, eleven extremes have been recorded regarding characteristic changes in displacement. The largest short-term movement was a compression of $0.04 \mathrm{~mm}$ in seven days, detected in March 2005, which coincided with the $25 \mathrm{~km}$ distant Ilirska Bistrica earthquake $\left(M_{\mathrm{L}}=3.9\right)$. About two months before the earthquake an extension of $0.05 \mathrm{~mm}$ occurred and one month before the earthquake the strain changed into a compression of $0.05 \mathrm{~mm}$. The largest permanent peak was detected at the end of 2004. Along the $y$-axis (Postojna 1) there was a dextral horizontal movement of $0.075 \mathrm{~mm}$ in one month (November 10 to December 15, 2004). After the sinistral horizontal movement of $0.02 \mathrm{~mm}$ (December 15-27, 2004), the $y$-axis retained its permanent position on $0.05 \mathrm{~mm}$, where it remained for more than a year. Regarding the extremes, ten earthquakes were selected that coincided with tectonic micro-displacements. In terms of speleogenesis, the monitored fault zone represents a stable cave environment. Because radon flux is known to change significantly during tectonic and seismic activities, radon air concentrations were monitored in parallel since 2006. During horizontal movements, either dextral or sinistral, radon pathways underground were partly closed, thus hindering radon migration and reducing its concentration in the cave air. Extension movements do not appear to have affected radon transport. Alternatively, the compression process (Postojna 2, February-August 2007) appears to have opened some new routes for radon transport, facilitating radon migration and increasing its concentration in air.
\end{abstract}

\section{INTRODUCTION}

Caves are very special environments where traces of different speleological events can be preserved for over $10^{6}$ years. However, caves are also dynamic environments. Karst waters forming underground passages use preferentially structural geological elements such as bedding planes, especially slipped bedding planes, fissures, faults, folds, etc. (Knez, 1996; Šebela, 1998; Kogovšek and Šebela, 2004; Šebela et al., 2004; Petrič and Šebela, 2004). In most studied cases, geological structures guiding the caves are no longer active. Some examples of active tectonics in karst described from different countries are included in Bini et al., 1992; Gilli and Delange, 2001; Mocchiutti and D'Andrea, 2002; and Plan et al., 2005.

Active tectonic structures in Postojna Cave have been monitored with TM 71 extensometers since 2004 (Šebela, 2005; Šebela et al., 2005; Gosar et al., 2007). Our goal was to detect the size and mechanism of tectonic movements along a well-expressed fault zone in the longest Slovenian cave and to evaluate the coincidence with seismic activity in that karst massif.
Beginning in 2006, we extended our study to include radon $\left({ }^{222} \mathrm{Rn}\right)$ as an indicator of tectonic and seismic activity. This radioactive noble gas originates from radioactive decay of ${ }^{226} \mathrm{Ra}$ in the ${ }^{228} \mathrm{U}$ radioactive decay chain in the Earth's crust. Only a fraction of the radon atoms created in a mineral grain emanate into the void space between grains, where they are dissolved either in water or in carrier gases, such as helium or nitrogen, and are thus transported by advection toward the ground surface and the atmosphere (Nero, 1988). This transport is influenced by a number of geophysical and geochemical parameters (Etiope and Martinelli, 2001).

Because in the area of faults the material is crushed, and hence more permeable to radon, the level of radon activity, either in the outdoor air or in soil gas at a fault, is generally

\footnotetext{
${ }^{1}$ Karst Research Institute SRC SASA, Titov trg 2, 6230 Postojna, Slovenia, sebela@zrc-sazu.si

${ }^{2}$ Jožef Stefan Institute, Jamova cesta 39, 1000 Ljubljana, Slovenia, Janja.Vaupotic@ijs.si

${ }^{3}$ Institute of Rock Structure and Mechanics, Academy of Sciences of the Czech Republic, V Holešovičkách 41, 18209 Prague, Czech Republic, košták@irsm.cas.cz, stemberk@irsm.cas.cz
} 
elevated. Changes in fault activity result in changing radon levels (Virk et al., 1997; Wu et al., 2003). In addition, the phenomena preceding and accompanying an earthquake can significantly change the radon pathways underground and thus govern radon levels appearing at the surface (Etiope and Martinelli, 2001). Thus, if radon is monitored in the outdoor air, soil gas, or thermal water, and a longterm time series of the resulting data is analyzed, in addition to regular fluctuations in radon levels ascribed to the effects of environmental conditions (e.g., temperature, barometric pressure), some anomalous increases or decreases in radon level may be observed and attributed to seismic events (Etiope and Martinelli, 2001).

In this study, radon was monitored continuously in Postojna Cave, together with measurements of micro movements. Micro tectonic movements and radon concentrations in air, observed at two sites at the Dinaric oriented (NW-SE) fault in the Postojna Cave, are examined in relation to seismic activity in the area. This is the first such comparative study between micro tectonic movements and radon air concentration to be investigated in a cave in Slovenia.

\section{Geology and Seismicity of the Study Area}

Slovenia is situated in the NE corner of the AdriaEurope collision tectonic zone. The Istria Peninsula (Fig. 1) contains the only outcrop of Adria microplate in the northern Adriatic region. The thrust belts of the Dinarides and Southern Alps form a rim of high topography around Adria. Major Dinaric (NW-SE) strike-slip faults cut and displace fold and thrust structures. Slovenia has considerable seismicity (Vrabec and Fodor, 2006), and this complex and neotectonically active region is of special interest because of the Classical Karst-Kras area (Fig. 2A).

Paleomagnetic data indicate that the motion of the Adriatic microplate has been associated with an approximately $30^{\circ}$ counterclockwise rotation (Márton et al., 2003) since the late Miocene or Pliocene. GPS measurements suggest sharp (some mm/year) dextral (transpressive) movements along the Sava Fault and Periadriatic Lineament (Fig. 1), showing that the side intrusion in the northeast Alps is still active (Weber et al., 2004).

The strongest earthquakes that have occurred in Slovenia in recent years were situated along the Ravne Fault (Bajc et al., 2001; Kastelic and Cunningham, 2006). Slovenia is considered to exhibit moderate seismicity, and the External Dinarides (Fig. 1), in particular, are characterized by moderate historic and recent seismicity. Regarding the fault plane solutions, it is evident that the governing stress in the region runs in an approximate N-S direction (Poljak et al., 2000).

According to a geological interpretation based on the analysis of repeated levelling line campaigns data along the Sečovlje-Bled polygon in western Slovenia, the active

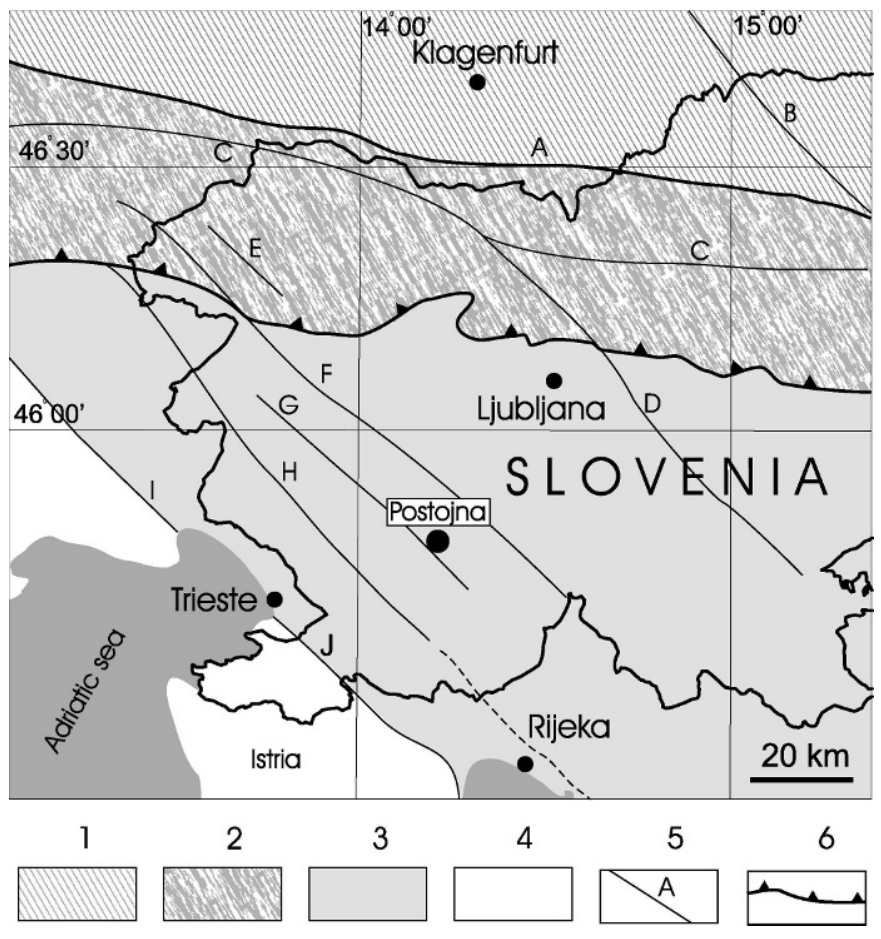

Figure 1. Tectonic situation of W Slovenia. 1-Eastern Alps (Alps), 2-Southern Alps (Dinarides), 3-External and Internal Dinarides, 4-Adriatic foreland, 5-Faults (A-Periadriatic Lineament, B-Labot Fault, C-Sava Fault, D-Stična Fault, E-Ravne Fault, F-Idrija Fault, G-Predjama Fault, H-Raša Fault, I-Palmanova Fault, J-Karst thrust edge), 6-Southalpine thrust front (after Poljak, 2007 and Placer, 1999).

tectonic structures (vertical movement) include at a minimum: a juvenile syncline between Strunjan and Koper, the Kras (Fig. 2A) Imbricate Structure, The Divača Fault, the Raša Fault, the Southalpine Front (Fig. 1), and the Julian Alps thrust (Rižnar et al., 2007). The Ravne Fault was responsible for the $1998\left(M_{\mathrm{W}}=5.6\right)$ and $2004(\mathrm{Krn}$, $M_{\mathrm{W}}=5.2$ ) earthquakes and appears to be an outstanding example of an actively propagating strike-slip fault cutting through pre-existing mountainous terrain (Kastelic and Cunningham, 2006).

LiDAR mapping to image seismogenic strike-slip faults in the Julian Alps in Slovenia was performed along the Idrija and Ravne Faults (Cunningham et al., 2006). One site (Kapa) in the Idrija LiDAR survey area may indicate some surface rupturing and other landscape features typically associated with strike-slip faulting. The Tolminka springs basin on the Ravne Fault is an example of a localized and active transtensional basin constructed within an overall transpressional system (Cunningham et al., 2006).

The strongest seismic event in the last 100 years around Postojna was the Cerknica earthquake (1926) $\left(M_{\mathrm{m}}=5.2\right)$ that probably originated on the Idrija Fault (Ribarič, 1982). The epicenter was $10 \mathrm{~km}$ east of Postojna. The 
S. Šebela, J. Vaupotič, B. KošŤÁa, and J. Stemberk

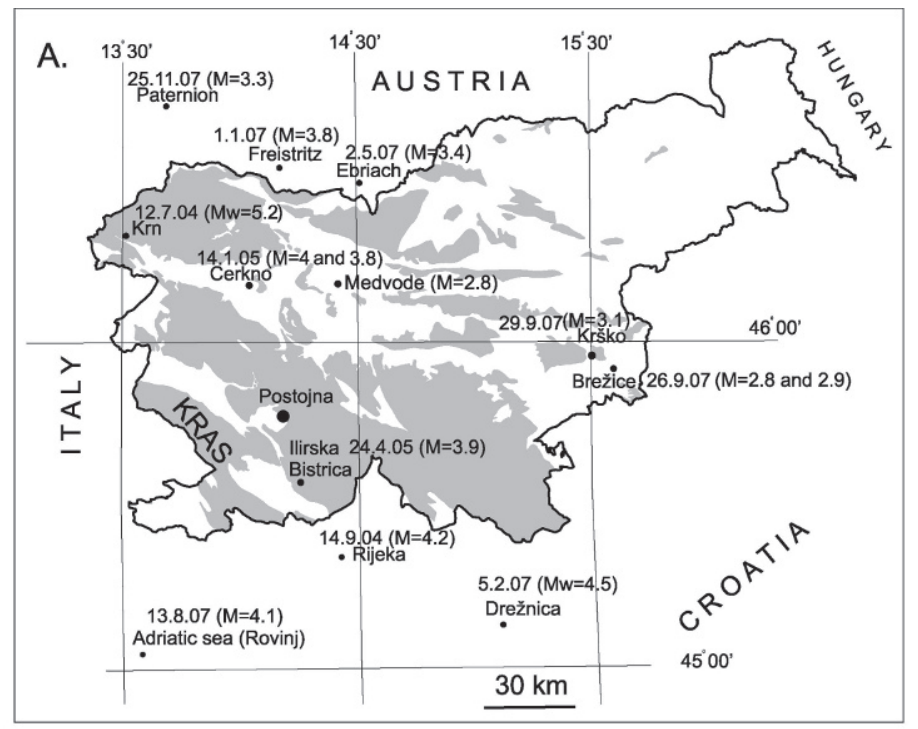

B.
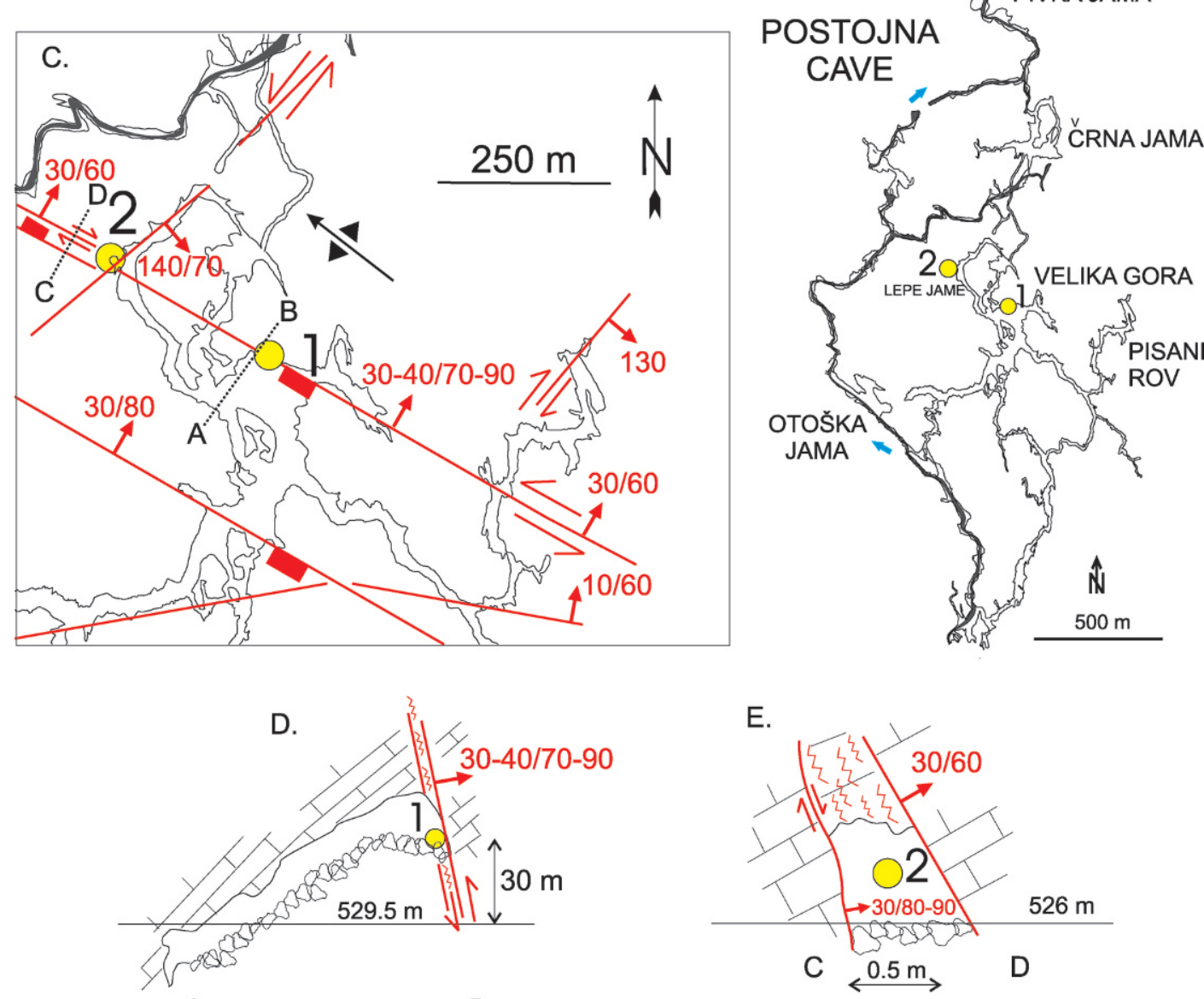

A

B
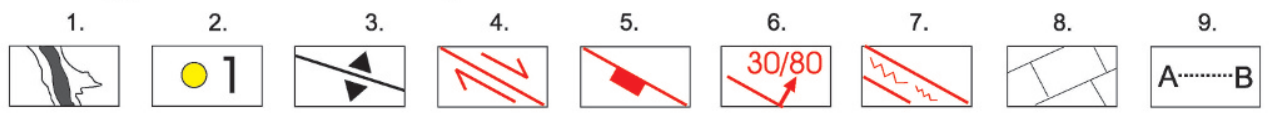

Šebela, 2009

Figure 2. Tectonic structure of Postojna Cave. A.-The position of Postojna and Kras in Slovenia with epicenters of the stronger earthquakes. Grey areas are karst outcrops, B.-The passages of Postojna Cave with monitoring sites (1-Postojna 1, 2-Postojna 2), C.-Structural-geological map of the monitoring sites, D.-AB cross section, E.-CD cross section, 1-Underground river Pivka, 2Monitoring sites: 1 (Postojna 1) and 2 (Postojna 2), 3-Postojna Anticline, 4-fault with horizontal (dextral) displacement, 5-fault with vertical displacement, 6-strike and dip of fault, 7-fault zone, 8-Upper Cretaceous limestone, 9-cross section. 
newspaper Edinost (Anonymous, 1926) reported that in Postojna Cave a large stalagmite, one meter in diameter, collapsed due to the earthquake.

\section{EXPERIMENTAL SETTING}

\section{Site Description}

The Postojna Cave (Fig. 2B), with $20 \mathrm{~km}$ of galleries, is the longest known cave system in Slovenia. The passages are developed in an approximately 800 -m-thick package of Upper Cretaceous bedded limestones (Šebela, 1998).

The cave is situated between two important Dinaric faults, the Idrija Fault on the north and the Predjama Fault on the south (Fig. 1). The tectonic structure of the area between these faults is characteristic of a transition zone between two dextral strike-slip faults. In Postojna Cave, we can distinguish older overthrusting and folding deformations and younger faulting deformations. Overthrusting took place after the deposition of Eocene flysch. During the Miocene and Pliocene, the overthrusting was accompanied by folding. The principal folding deformation in the cave is the Postojna Anticline. Cave passages are developed in both flanks of the anticline (Fig. 2C) and follow the strike and dip of the bedding-planes, especially those with interbedded slips (Čar and Šebela, 1998).

The northern edge of Velika Gora (Fig. 2C and 2D) is developed along the Dinaric oriented (NW-SE) reverse fault zone, with traces of vertical displacement for some meters (Fig. 2C, monitoring site Postojna 1). The same fault zone from Velika Gora can be traced in some parts of the cave, but other parts do not exhibit the same tectonic characteristics. In the SE part of the cave, a horizontal sinistral movement with $60^{\circ}$ dip angle for fault zone NW from Velika Gora is observed. The same fault zone exhibits vertical and horizontal displacements (Fig. 2C, monitoring site Postojna 2) and is cut by the cross-Dinaric fault zone (Sasowsky et al., 2003). Different tectonic activities are observed on the same Dinaric-oriented fault zone, sometimes with four individual tectonic phases.

The locations for installation of the extensometers in Postojna Cave were selected to evaluate if the monitored fault is tectonically active and to determine whether the tectonic activity has any influence on speleogensis. The two devices were installed in the same fault zone but on different fault planes. Postojna 1 was installed at the contact point between a fault plane (dip angle $70-90^{\circ}$ to the NE) and a collapse block, partly covered with flowstone (Figs. 2D and 3). The second device (Postojna 2) was installed in a narrow natural passage, which was enlarged artificially 30 -years-ago, between two fault planes that are about one half meter apart (Figs. 2E and 4). The northern fault plane dips to the NE at $60^{\circ}$ and has horizontal striation, representing dextral movement. The southern one constitutes the normal fault, dipping towards the NE by $80-90^{\circ}$ and shows vertical striation. The fault zone being monitored is about $1,000 \mathrm{~m}$ north of the inner zone of the

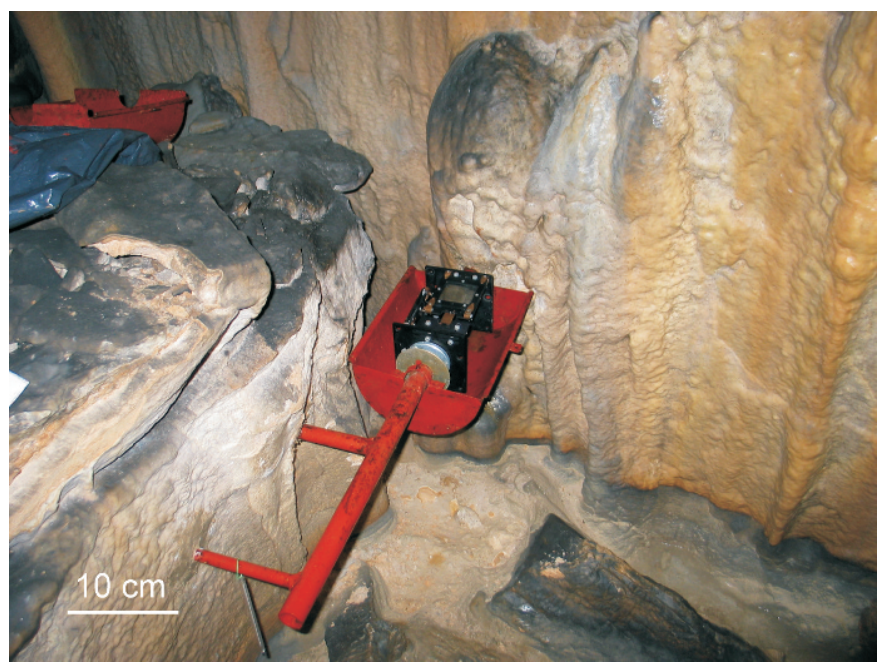

Figure 3. Monitoring site Postojna 1 with TM 71 instrument (photo S. Šebela).

Predjama Fault (Fig. 1). Postojna 1 is $68 \mathrm{~m}$ below ground surface and Postojna 2 is $60 \mathrm{~m}$ below ground surface and about $1,400 \mathrm{~m}$ from the entrance to the cave.

\section{Measurement Techniques}

\section{Measurement of Micro Movements}

We employed a TM 71 extensometer, developed by Blahoslav Košták (Košták, 1969). This is a mechanooptical instrument that measures displacement in three dimensions $(x, y$ and $z$ ). It works on the principle of the Moiré optical effect, which changes when two transparent plates move (Košták, 1977; 1991). Each plate is fixed into the outcrop of a fault plane or fissure. The instrument is very robust and simple, and needs no source of energy. This is good for long-term observations under varying

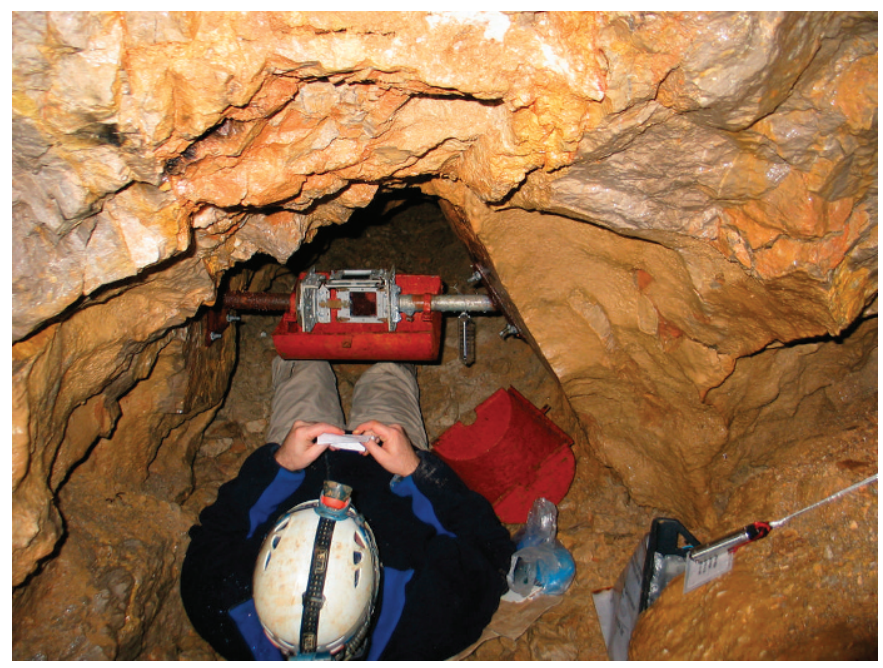

Figure 4. Monitoring site Postojna 2 with TM 71 instrument (photo S. Šebela). 
meteorological conditions (Avramova-Tacheva and Košták, 1995). The characteristic of the TM 71 is long-term measurement of movements accurate to within $0.01 \mathrm{~mm}$.

Measurements at Postojna 1 began May 26, 2004 and at Postojna 2 on February 26, 2004. The instruments are set permanently at the sites and their readings are taken generally once a month. Because the cave temperature is stable throughout the year $\left(9^{\circ} \mathrm{C}\right.$ to $\left.11{ }^{\circ} \mathrm{C}\right)$, any influence of temperature on data records can be disregarded. The measurements have an evaluation accuracy of $0.01 \mathrm{~mm}$ in all three displacement co-ordinates, $x, y$ and $z$.

\section{Measurement of Radon}

Barasol probes (MC-450, ALGADE, France) were used during the first two years, and then replaced by Radim 5 WP monitors (SMM Company, Prague, Czech Republic). The Barasol probe is designed primarily for radon measurements in soil gas. The probe gives radon concentration, based on alpha spectrometry of radon decay products in the energy range of $1.5 \mathrm{MeV}$ to $6 \mathrm{MeV}$ using an implanted silicon detector. The detector sensitivity is $50 \mathrm{~Bq}$ $\mathrm{m}^{-3}$ with a sampling frequency of four times an hour. In addition to radon concentration, the probe also records temperature and barometric pressure. The Radim 5 monitor is used mostly for radon measurements of indoor air. It determines radon concentration by measuring gross alpha activity of the decay products ${ }^{218} \mathrm{Po}$ and ${ }^{214} \mathrm{Po}$, collected electrostatically on the surface of a semiconductor detector. The sensitivity is about $50 \mathrm{~Bq} \mathrm{~m}^{-3}$ and the sampling frequency is twice an hour. Data are stored in the inner memory of both instrument and then transferred to a personal computer for further evaluation, usually once every two months. Instruments are checked regularly, using a portable AlphaGuard radon monitor (Genitron, Germany) as a reference instrument. Radon measurements were collected from the beginning of April through October 2007 at Postojna 1 (Fig. 7) and from October 2006 through October 2007 at Postojna 2 (Figs. 8 and 9).

Hourly average values of the outdoor air temperature at the Postojna meteorological station were obtained from the Office of Meteorology of the Environmental Agency of the Republic of Slovenia. Data on seismic events were obtained from the Office of Seismology of the same Agency. We considered only those earthquakes for which the magnitude $M_{\mathrm{L}}$ was higher than 2 and the distance $R$ between our measurement site and the epicenter was less than 3 times Dobrovolsky's (Dobrovolsky et al., 1979) radius $R_{\mathrm{D}}$, defined by $R_{\mathrm{D}}=10^{0.43 \times M_{\mathrm{L}}}$. Origin 6.1 Data Analysis and Graphing Software were used for statistical data evaluation and presentation.

\section{Results AND Discussion}

\section{Micro Displacements}

The measurement results include three coordinates, $x, y$, $z$, which are principally perpendicular to the observed fault zone (i.e., $+x$ represents compressive movement of the monitored fault zone, $+y$ represents sinistral-lateral movement, and $+z$ vertical movement) relative shear in the fault: $\mathrm{N}$ subsidence or $\mathrm{S}$ uplift. Displacements recorded at both sites (Figs. 5 and 6) are generally small, the range of movements being within $0.1 \mathrm{~mm}(+0.02$ to -0.075$)$. The plots show a number of sharp peaks. However, the development of such peaks in individual coordinates generally could not be matched between the two monitored sites. Some peaks are thus due to records close to the limits of recording accuracy. A certain similarity, however, can be observed between the two sites regarding the trend of development and periods of unrest. The total length of the displacement vector at each of the two sites developed parallel increasing short-term trends of about $0.1 \mathrm{~mm} \mathrm{yr}^{-1}$ in the period July 2004-March 2005; later the trend fell to zero.

Detailed analysis of the individual coordinates show evidence of some periods of unrest alternating with more quiet periods. Movements detected in the $y$-and $z$-axes for both instruments were simultaneous, which suggests real tectonic movements. In general, unrest was recorded from the start of measurements at the beginning of 2004 until about March 2005, and then again during the period from October 2006 to January 2008.

Extremes (E) of the periods of unrest (Figs. 5 and 6) are indicated at the following periods/sites/coordinates/dates:

(a) E1: Postojna $2 / x \rightarrow-0.055 \mathrm{~mm} /$ March-June 2004 (March 11 to June 29, extension; June 29 to July 13, compression; Krn earthquake July 12, 2004);

E2: Postojna $1 / z \rightarrow-0.03 \mathrm{~mm} /$ May-June 2004;

(b) E3: Postojna $1 / x \rightarrow-0.04 \mathrm{~mm} / \mathrm{July} 30$ to December 15, 2004 (extension); $\mathrm{x} \rightarrow-0.02 \mathrm{~mm} /$ December 27, 2004 to January 26, 2005 (extension);

E4: Postojna $1 / y \rightarrow-0,075 \mathrm{~mm} /$ November 10, 2004 to December 15, 2004 (dextral horizontal movement); December 15 to December 27, 2004 (sinistral horizontal movement)-permanent change of $0.05 \mathrm{~mm}$;

E5: Postojna $2 / z \rightarrow-0.03 \mathrm{~mm} /$ September-November 2004;

E6: Postojna $2 / z \rightarrow-0.05 \mathrm{~mm} /$ February-March 2005 $(+0.04 \mathrm{~mm}$ in 7 days);

E7: Postojna $2 / x \rightarrow-0.04 \mathrm{~mm} / \mathrm{January}-$ March 2005 ; January 14 to March 22, 2005 (extension); March 22 to May 6, 2005 (compression); Ilirska Bistrica earthquake April 24, 2005;

E8: Postojna 2/y $\rightarrow-0.04 \mathrm{~mm} /$ January-March 2005; January 14, to February 23, 2005 (dextral horizontal movement); March 29 to May 6, 2005 (sinistral horizontal movement); Cerkno earthquakes January 14, 2005; Ilirska Bistrica earthquake April 24, 2005; E9: Postojna $1 / z \rightarrow-0.02 \mathrm{~mm} / \mathrm{January}-$ March 2005; (the value in the error limit);

(c) E10: Postojna 2/y $\rightarrow-0.025 \mathrm{~mm} /$ October 2006January 2007; October 13 to November 16, 2006

Journal of Cave and Karst Studies, April 2010 25 

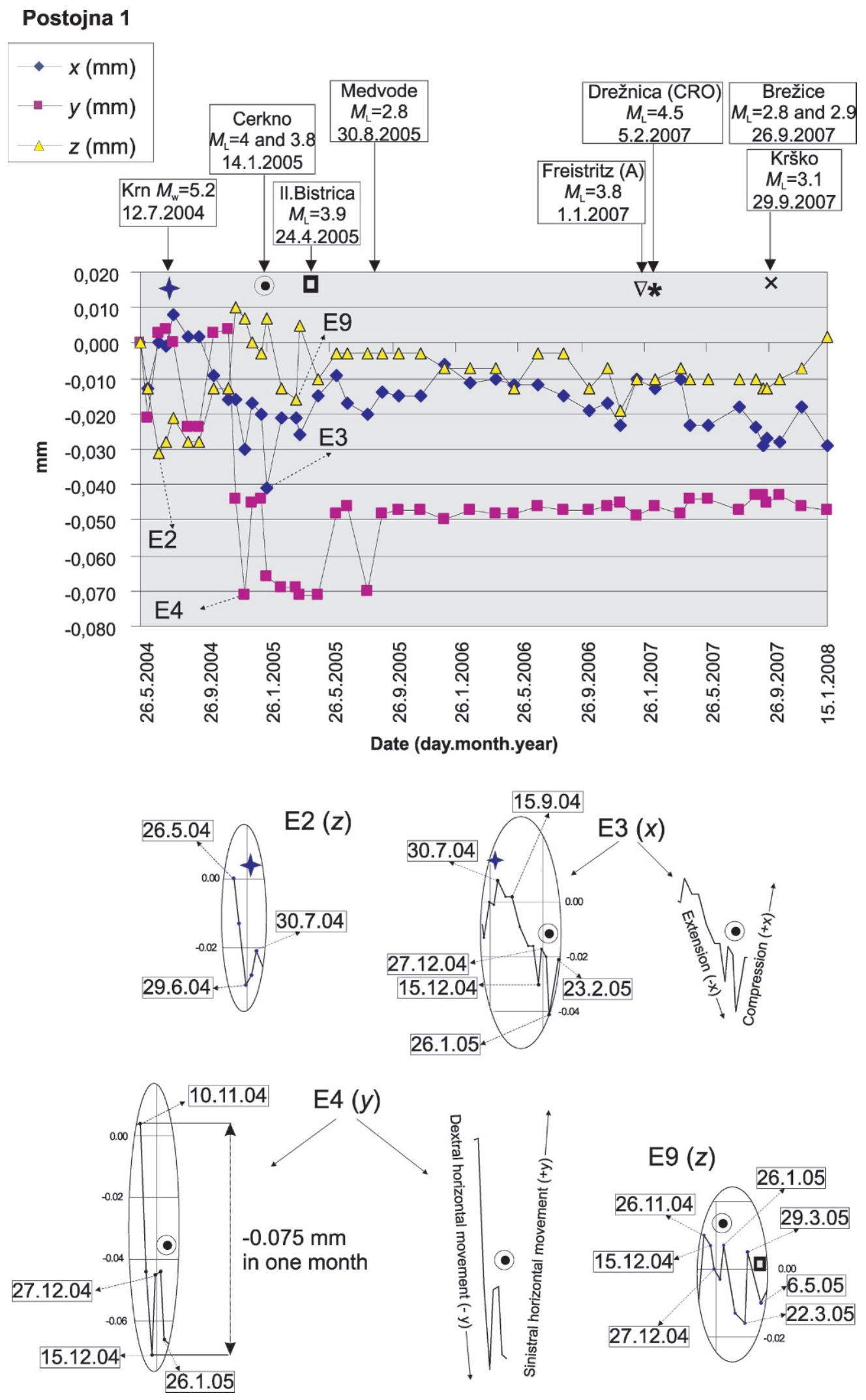

Figure 5. Displacements recorded by TM 71 at Postojna 1 monitoring site. 
Postojna 2

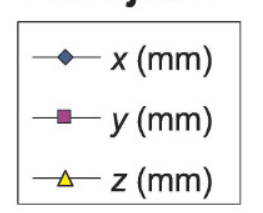

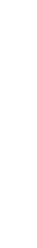
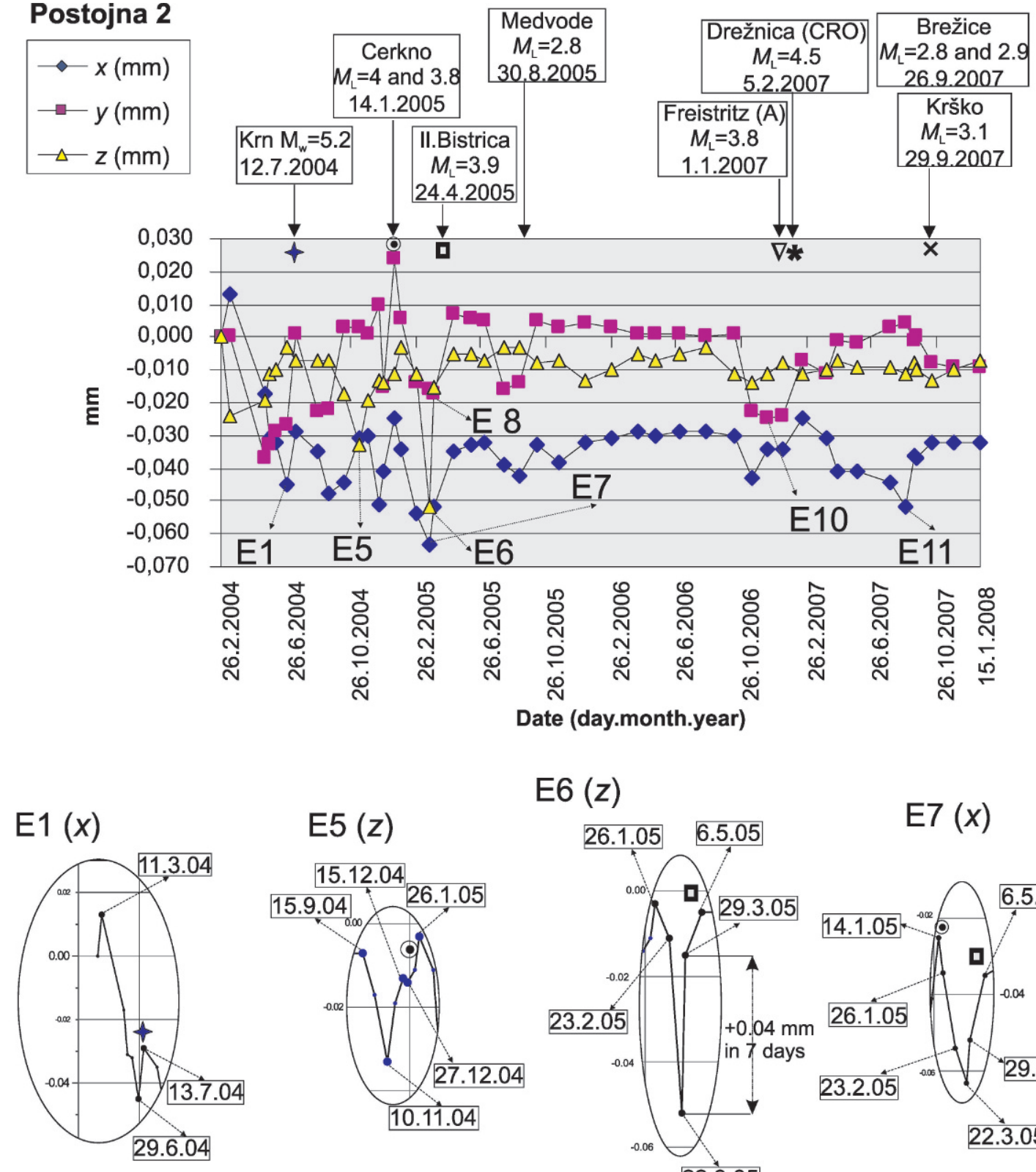

E6 ( $z)$

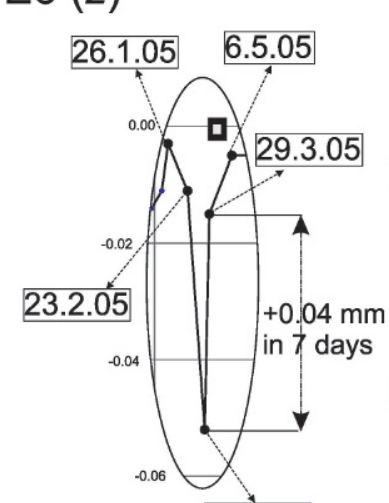

$\mathrm{E} 7(x)$
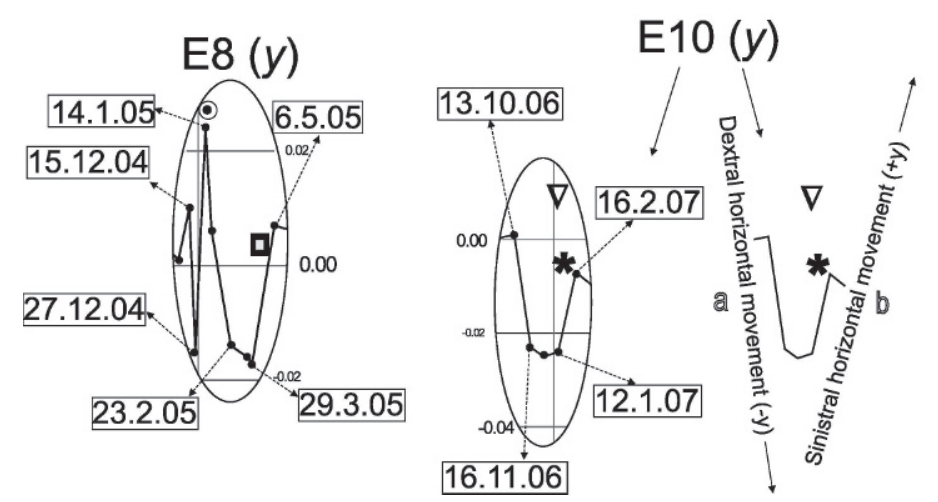

22.3 .05

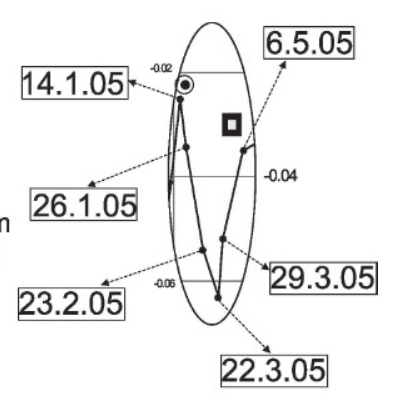

22.3 .05

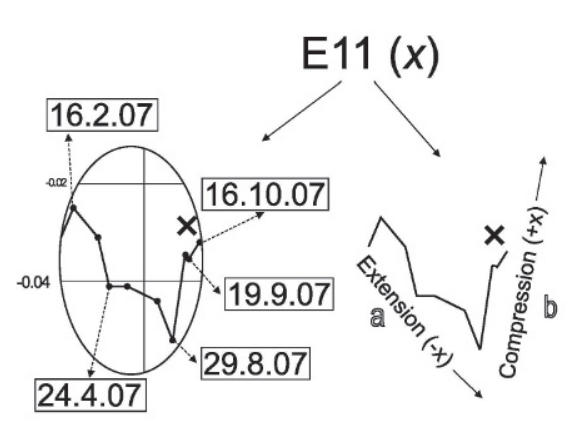

Figure 6. Displacements recorded by TM 71 at Postojna 2 monitoring site. 


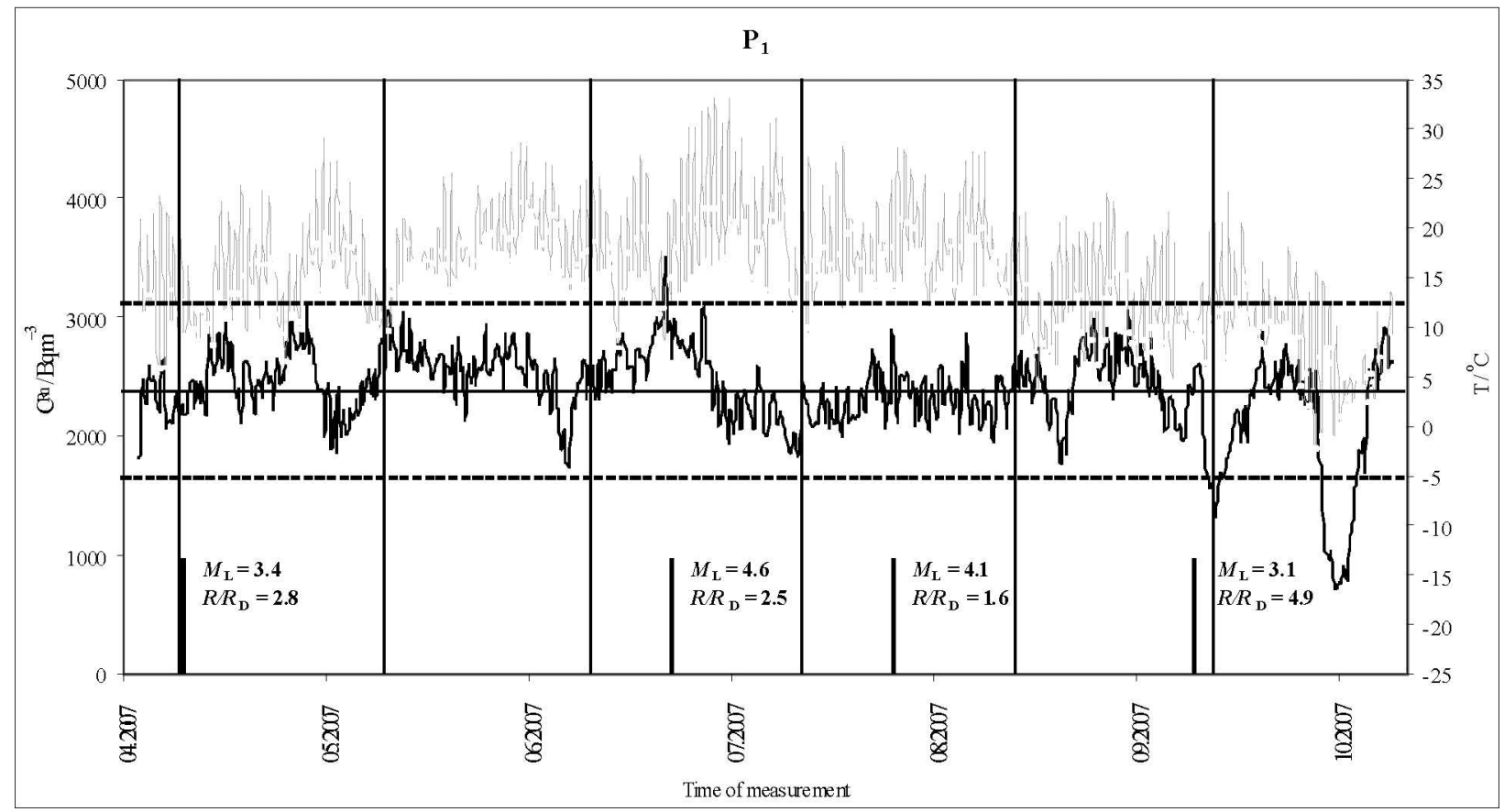

Figure 7. Time series plot of radon concentration in air (black line) at the Postojna 1 site and temperature of the outdoor air (grey line) at the Postojna Meteorological Station (April-October 2007); the relevant earthquakes are inserted, with $M_{\mathrm{L}}$ and $R / R_{\mathrm{D}}$ values indicated, $M_{\mathrm{L}}=3.4$ (Ebriach, Austria), $M_{\mathrm{L}}=4.6\left(38 \mathrm{~km}\right.$ south from Zadar, Croatia), $M_{\mathrm{L}}=4.1$ (near Rovinj, Croatia), $M_{\mathrm{L}}=3.1$ (Krško, Slovenia) (see Table 1).

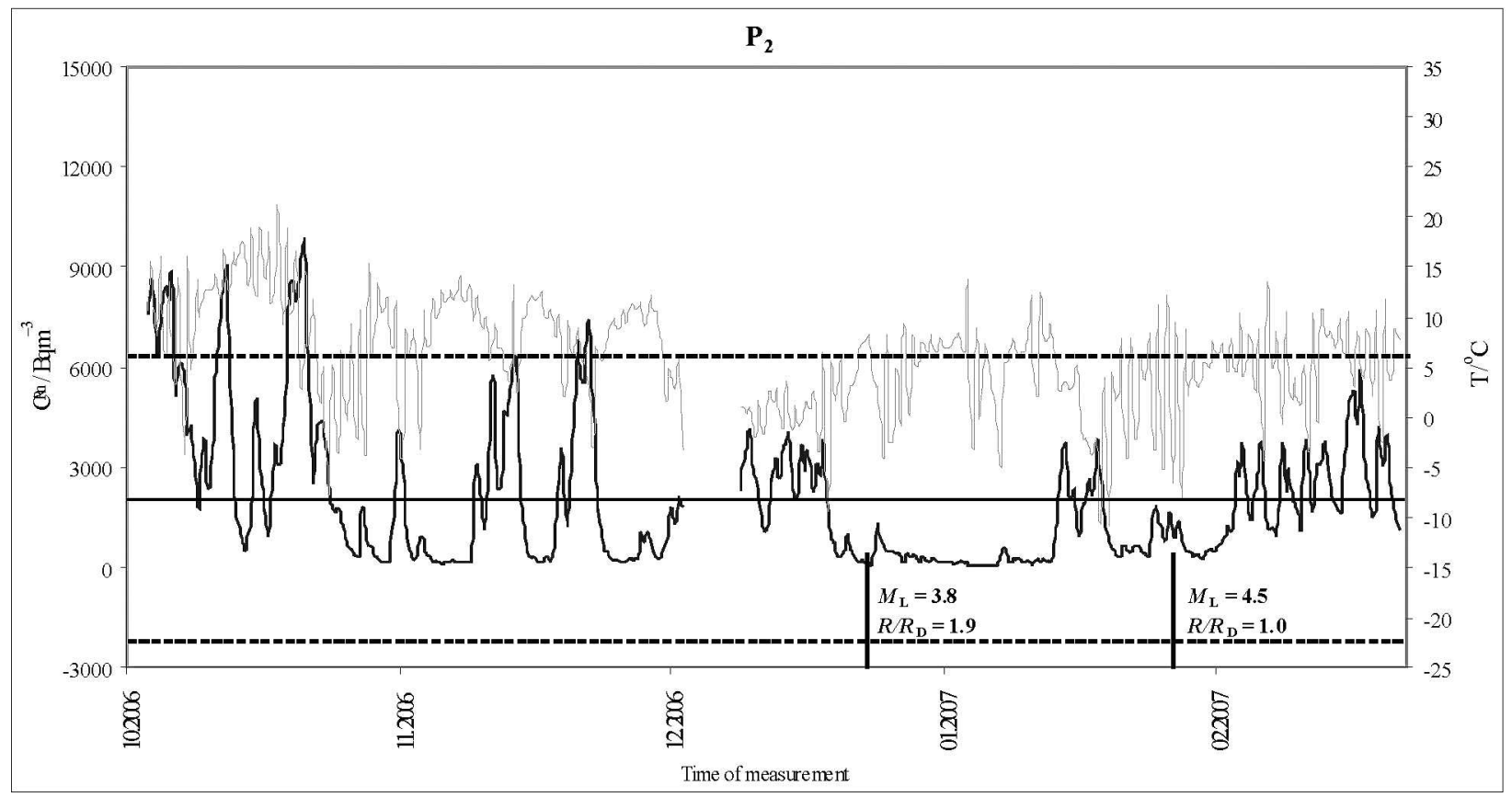

Figure 8. Time series plot of radon concentration in air (black line) at the Postojna 2 site and temperature of the outdoor air (grey line) at the Postojna Meteorological Station (October 2006-March 2007); the relevant earthquakes are inserted, with $M_{\mathrm{L}}$ and $R / R_{\mathrm{D}}$ values indicated, $M_{\mathrm{L}}=3.8$ (Freistritz, Austria), $M_{\mathrm{L}}=4.5$ (Drežnica, Croatia) (see Table 1). 


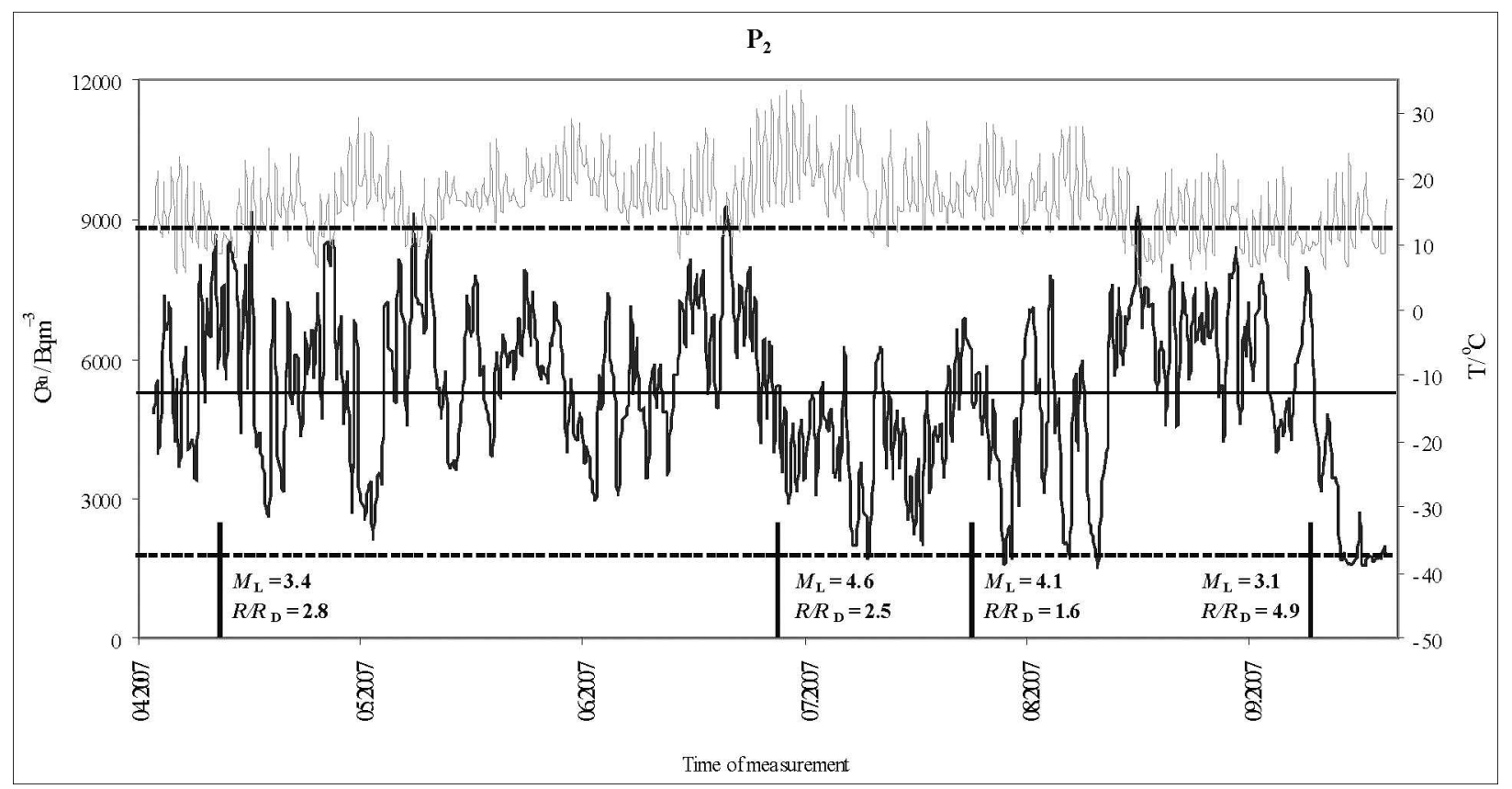

Figure 9. Time series plot of radon concentration in air (black line) at the Postojna 2 site and temperature of the outdoor air (grey line) at the Postojna Meteorological Station (April-October 2007); the relevant earthquakes are inserted, with $M_{\mathrm{L}}$ and $R / R_{\mathrm{D}}$ values indicated, $M_{\mathrm{L}}=3.4$ (Ebriach, Austria), $M_{\mathrm{L}}=4.6$ (38 km south from Zadar, Croatia), $M_{\mathrm{L}}=4.1$ (near Rovinj, Croatia), $M_{\mathrm{L}}=3.1$ (Krško, Slovenia) (see Table 1).

(dextral horizontal movement); January 12 to February 16, 2007 (sinistral horizontal movement); Freistritz earthquake (Austria) January 1, 2007; Drežnica earthquake (Croatia) February 5, 2007;

E11: Postojna $2 / x \rightarrow-0.035 \mathrm{~mm} /$ February-August 2007; February 16 to August 29, 2007 (extension); August 29 to October 16, 2007 (compression).

When looking for earthquakes that might coincide with the registered displacements we found 10 events (Table 1, Figs. 5 and 6). The first was the Krn earthquake of July 12, $2004\left(M_{\mathrm{w}}=5.2\right)$, which had an epicenter $70 \mathrm{~km} \mathrm{NW}$ from the measuring sites. The earthquake occurred during the period of E1 and E2 when some fault opening along the $x$ axis at Postojna 2 (Fig. 6) and vertical movements along $z$ axis at Postojna 1 (Fig. 5) were recorded. Lateral movements observed at Postojna 1 and 2 during the (a) period were of special interest and were first reported by Šebela et al. (2005). Before the earthquake, the displacement along the $y$-axis corresponded to dextral lateral movement, and just before or during the earthquake, the movement changed to sinistral, with a step of about $0.03 \mathrm{~mm}$ (Šebela et al., 2005).

The second event, comprising two earthquakes (Cerkno, $M_{\mathrm{L}}=4.0$ and 3.8 on January 14, 2005), appeared in the (b) period, just after the extreme E4 in the $y$-axis (Fig. 5) that represents a dextral lateral slip of $-0.075 \mathrm{~mm}$. The most significant change in our observations appeared between November 10 and December 15, 2004. Between
December 15, 2004 and Decemebr 27, 2004 movement on the $y$-axis was $+0.03 \mathrm{~mm}$ (horizontal sinistral lateral slip). After the event, the step on the $y$-axis remained at about $-0.05 \mathrm{~mm}$, where it remains today. On December 26, 2006, the large Sumatra earthquake $\left(M_{\mathrm{W}}=9.2\right)$ occurred. Can long-distant changes in stress and strain in the Earth's crust be an alternative cause of the big step or we registered just a coincidence? The slip registered on the $y$-axis at Postojna 2 was not as large as that registered at Postojna 1, even if we are observing the same fault zone, but not the same fault line. The movement on the $y$-axis (Postojna 2, first peak on E8) was $-0.02 \mathrm{~mm}$ (dextral lateral slip from December 15 to December 27, 2004) and $+0.04 \mathrm{~mm}$ (sinistral lateral slip from December 27, 2004 to January 14, 2005). During the Cerkno earthquakes, the TM 71 instrument registered significant movements on the $z$-axis (E5) at the Postojna 2 site (Fig. 6).

The extreme E6 on the $z$-axis (Fig. 6) appeared before the Ilirska Bistrica earthquake (April 24, 2005, $M_{\mathrm{L}}=3.9$ ) that was situated $25 \mathrm{~km}$ SE from Postojna. From March 22 until March 29, 2005, $+0.04 \mathrm{~mm}$ was registered in seven days on the $z$-axis, the largest displacement recorded in one week. The Cerkno earthquakes and the Ilirska Bistrica earthquake occurred during three extremes (E6, E7 and E8; Postojna 2, Fig. 6). At Postojna 1, during the period of the Cerkno-Ilirska Bistrica earthquakes, we detected small displacements along the $z$ (E9) and $y$-axes $(-0.02 \mathrm{~mm})$ (Fig. 5). 
Table 1. Stronger earthquakes in Slovenia and neighbouring countries during the period of monitoring (sources: Ministry for Environment and Spatial Planning, Environmental Agency of the Republic of Slovenia, 2008, Seismology: http://www.arso. gov.si/potresi/ [accessed January 9, 2008] and European-Mediterranean Seismological Center, 2008, Database of Local Seismological Bulletins from European-Mediterranean Networks: http://www.emsc-csem.org/index.php?page=data\&sub=base [accessed January 9, 2008]).

\begin{tabular}{|c|c|c|c|c|}
\hline Date & Depth, km & $M_{\mathrm{L}}$ & Location & Air distance from Postojna \\
\hline July 12, 2004 & 13 & $M_{\mathrm{w}}=5.2$ & Krn & 70 km NW \\
\hline September14, 2004 & $8,9(?)$ & 4.2 & Fužine-Rijeka (Croatia) & $50 \mathrm{~km}$ south \\
\hline September 22, 2004 & 16 & 3.5 & Zgornji Prekar & 70 km NE \\
\hline November 24, 2004 & 25 & 5.2 & Manerba del Garda (Italia) & $290 \mathrm{~km} \mathrm{~W}$ \\
\hline November 25, 2004 & 15 & 5.2 & Jabuka (Croatia) & $310 \mathrm{~km} \mathrm{~S}$ \\
\hline January 14, 2005 & 20 & 4 & Cerkno & $45 \mathrm{~km} \mathrm{NW}$ \\
\hline January 14, 2004 & 20 & 3.8 & Cerkno & $45 \mathrm{~km} \mathrm{NW}$ \\
\hline April 24, 2005 & 17 & 3.9 & Ilirska Bistrica & $25 \mathrm{~km} \mathrm{SE}$ \\
\hline August 30, 2005 & 18 & 2.8 & Medvode & $45 \mathrm{~km} \mathrm{NE}$ \\
\hline November 24, 2005 & 16 & 2.5 & Postojna & $5-10 \mathrm{~km} \mathrm{~W}$ \\
\hline December 12, 2005 & 19 & 2.9 & Žiri & 30 km NW \\
\hline January 30, 2006 & 12 & 2.1 & Prestranek & $10-15 \mathrm{~km}$ south \\
\hline June 21, 2006 & 16 & 2.8 & Gorski Kotar (Croatia) & 70 km SE \\
\hline August 30, 2006 & 22 & 2.4 & Škofja Loka & $45 \mathrm{~km}$ north \\
\hline September 3, 2006 & 13 & 2 & Podnanos & $22 \mathrm{~km} \mathrm{~W}$ \\
\hline September 24, 2006 & 15 & 2.2 & Podnanos & $22 \mathrm{~km} \mathrm{~W}$ \\
\hline January 1, 2007 & 16 & 3.8 & Freistritz/Bistrica v Rožu (Austria) & $80 \mathrm{~km}$ north \\
\hline February 5, 2007 & 10 & $M_{\mathrm{w}}=4.5$ & Drežnica (Croatia) & $90 \mathrm{~km}$ south \\
\hline May 2, 2007 & 16 & 3.4 & Ebriach/Obirsko (Austria) & 80 km NE \\
\hline July 18, 2007 & $?$ & 4.6 & $38 \mathrm{~km}$ south from Zadar (Croatia) & $240 \mathrm{~km} \mathrm{SE}$ \\
\hline August 13, 2007 & 27 & 4.1 & Adriatic sea, near Rovinj (Croatia) & $95 \mathrm{~km} \mathrm{SW}$ \\
\hline September 26, 2007 & 3 & 2.8 & Brežice & $115 \mathrm{~km} \mathrm{E}$ \\
\hline September 26, 2007 & 5 & 2.9 & Brežice & $115 \mathrm{~km} \mathrm{E}$ \\
\hline September 29, 2007 & 10 & 3.1 & Krško (Raka) & 105 km E \\
\hline November 25, 2007 & 12 & 3.3 & Paternion (Austria) & $107 \mathrm{~km} \mathrm{NW}$ \\
\hline
\end{tabular}

$M_{\mathrm{L}}=$ local magnitude

$M_{\mathrm{W}}=$ moment magnitude

Between May 6, 2005 and October 13, 2006, the Postojna 2 monitoring site was very stable on all three axes. The only reliable disruption (Fig. 6) was from July 1 to October 7, 2005 during the Medvode earthquake (August 30, 2005, $M_{\mathrm{L}}=2.8$ ), being about $0.02 \mathrm{~mm}$ along $y$-axis. A displacement peak of about $0.02 \mathrm{~mm}$ was also recorded along the $y$-axis at Postojna 1 (Fig. 5), from July 1 to September 7, 2005.

The Postojna 1 site was very stable from June 9, 2005 until the beginning of 2007. Even during the earthquakes in 2007 , significant movements were not detected, the $y$-axis in particular being very stable. During the third time (c) period (the year 2007), some movements on Postojna 2 (E10 and E11) were recorded. During the earthquakes in Austria (Freistritz, January 1, 2007, $M_{\mathrm{L}}=3.8$ ) and in Croatia (Drežnica, February 5, 2007, $M_{\mathrm{L}}=4.5$ ) we detected movement along the $y$-axis by $-0.025 \mathrm{~mm}$ (E10). The Brežice (September 26, 2007, $M_{\mathrm{L}}=2.8$ and 2.9) and Krško earthquakes (September 29, 2007, $M_{\mathrm{L}}=$ 3.1) in Eastern Slovenia coincided with an extension along the $x$-axis of $-0.035 \mathrm{~mm}$ from February 16 until August
29, 2007 and with a compression of $+0.025 \mathrm{~mm}$ between August 29, 2007 and October 16, 2007. The fact that movements were recorded both before and after the earthquakes is important. Preceding movements, based on observation of micro-movements, have also been reported on several other occasions in Europe (Košták et al., 2007; Stemberk and Košták, 2007).

Monitoring results show small movements along all three axes. At Postojna 1 (Fig. 5), $-0.05 \mathrm{~mm}$ dextral lateral movement (y-axis) was recorded over four years, and at Postojna 2 (Fig. 6), an extension of $-0.03 \mathrm{~mm}$ over four years was recorded. The short-term rate of change averaged $-0.05 \mathrm{~mm} \mathrm{yr}^{-1}$ at Postojna 1 in the first year of monitoring (2004). The measurements for the $y$-axis in the year 2006 were very stable for both devices and show no movement at all.

The micro displacements determined in Postojna Cave were very small and frequently within the limits of error $(0.01 \mathrm{~mm})$. However, on the basis of some obvious extremes that generally coincided with seismic activity and of silent periods with almost no movement (Figs. 5 and 
6), we believe that slow tectonic processes are being monitored within the aseismic fault zone.

In 2004 and the first part of 2005, some significant peaks, the largest being $0.075 \mathrm{~mm}$ in one month on the $y$ axis, were registered at Postojna 1 (Fig. 5, E4). From September 2005 till January 2008 (Fig. 5), the Postojna 1 monitoring site was very stable, especially along the $y$-axis. Because the extensometer is fixed between the collapse block and the fault wall of the collapse chamber (Fig. 3), we would expect some non-tectonic movements due to the instability of the collapse blocks, especially on the $z$-axis. The only two marked extremes along the $z$-axis (Fig. 5, E2 and E9) are very small, $0.020-0.025 \mathrm{~mm}$, and coincided with the Krn, Cerkno and Ilirska Bistrica earthquakes. The stability of the largest collapse chamber in the cave, Velika Gora, is in this sense, very high.

The Postojna 2 site (Fig. 4) is in an artificially enlarged small natural passage, where the extensometer is fixed between two striated fault planes. The curves show some well-expressed peaks (Fig. 6), some of which coincide with earthquake activity. The highest extremes (E1 and E6, Fig. 6) do not exceed $0.05 \mathrm{~mm}$. The calm period starting in September 2005 was interrupted at the end of September 2006. In 2007, two extremes (Fig. 6, E10 and E11) were concurrent with the Freistritz, Drežnica, Brežice and Krško earthquakes.

Even though we are observing the same Dinaricoriented fault zone, the same response is not, in general, observed at the two monitoring sites that are separated 260-m-horizontally and 33.5-m-vertically (Fig. 2). One of the causes can be that the Dinaric-oriented fault is cut by a relatively younger cross-Dinaric fault (Sasowsky et al., 2003). Another fact is that the same fault zone is not necessarily tectonically active to the same degree along its length. Along the monitored fault zone we have found traces of at least four different old movements, but recent, very slow tectonic movements, that are showing a general horizontal dextral-lateral movement (Postojna 1) and extension (Postojna 2), are in agreement with the active tectonic situation on Dinaric faults in SW Slovenia. The earthquakes (Table 1) with lower magnitudes, even those close $(5-22 \mathrm{~km})$ to the monitoring sites, do not coincide with the micro-tectonic movements.

\section{RADON LEVELS}

Time series of radon activity concentrations $\left(C_{\mathrm{Rn}}\right.$ in $\mathrm{Bq}$ $\mathrm{m}^{-3}$ ) were measured at Postojna 1 and Postojna 2 (Figs. 7, 8 and 9) and recorded in parallel with the outdoor air temperature. $C_{\mathrm{Rn}}$ at Postojna 1 (Fig. 7) showed regular diurnal fluctuations, as previously observed at other locations in the cave (Vaupotic et al., 2001). The arithmetic mean of $C_{\mathrm{Rn}}$ over the whole period of monitoring is $2380 \pm$ $376 \mathrm{~Bq} \mathrm{~m}^{-3}$. During this time, no unrest was recorded at Postojna 1 and no effect of the unrest at Postojna 2 on radon level at Postojna 1 can be seen (extension until August 29 and compression from August 29 to October 16,
2007; Fig. 6). None of the earthquakes on May 2, 2007 $\left(M_{\mathrm{L}}=3.4, R / R_{\mathrm{D}}=2.8\right)$, July $18,2007\left(M_{\mathrm{L}}=4.6, R / R_{\mathrm{D}}=\right.$ $2.5)$ or August 13, $2007\left(M_{\mathrm{L}}=4.1, R / R_{\mathrm{D}}=1.6\right)$ appear to have had any connection, although their magnitudes were relatively high for the region and their $R / R_{\mathrm{D}}$ values quite low (Zmazek et al., 2003). The decrease in $C_{\mathrm{Rn}}$ after September 26, 2007 (Fig 7) cannot be paralleled with earthquakes that occurred in the period September 26, 2007 to September 29, 2007 because their epicenters were too far away $\left(R / R_{\mathrm{D}}\right.$ between 4.8 and 7.1$)$ although their magnitudes were not so low for the region $\left(M_{\mathrm{L}}\right.$ from 2.1 to 3.1). This decrease in $C_{\mathrm{Rn}}$ was most probably caused by decreases in outdoor air temperature. It is well known that radon level in the Postojna Cave is governed mainly by the so called chimney effect (Vaupotič et al., 2001; Vaupotič, 2008). The cave system behaves as a huge fireplace: when the outdoor air temperature falls below the temperature of the cave, the air current from the warmer cave carries radon-rich air towards the outdoor air, causing fresh outdoor air with low radon levels to enter the cave and reducing the $C_{\mathrm{Rn}}$ in the cave. This occurred at Postojna 1 towards the end of September 2007 (Fig. 7) when the outdoor air temperature, which was below $0{ }^{\circ} \mathrm{C}$ for several days, fell far below the cave temperature. The arithmetic mean of $C_{\mathrm{Rn}}$ without the contribution after September 26, 2007 is $2445 \pm 275 \mathrm{~Bq} \mathrm{~m}^{-3}$ and may be considered as the summer radon level at Postojna 1.

During radon monitoring at Postojna 2, two tectonic unrest periods were observed, E10(y) and E11(x) (Fig. 6). These may be further subdivided: $\operatorname{E10}(y)$ into (1) $\operatorname{E10a}(y)$ : dextral horizontal movement starting on October 13, 2006 (before radon measurement had started) and ending on November 16, 2006, and (2) E10b(y) sinistral horizontal movement from January 12 to February 16, 2007); and E11(x) into (1) E11a(x) extension from February 16 to August 29, 2007, and (2) E11b(x) compression from August 29 to October 16, 2007. The diurnal variations in $C_{\mathrm{Rn}}$ are different from those observed at Postojna 1, thus presumably indicating the effect of micro movements on the transport of radon and its entry into the cave air.

The overall arithmetic mean $C_{\mathrm{Rn}}$ (tot) for Postojna 2 (Figs. 8 and 9) during the entire period of monitoring (October 2006-October 2007) is $3853 \pm 2527 \mathrm{~Bq} \mathrm{~m}^{-3}$, being about $60 \%$ higher than at Postojna 1 . The standard deviation is high because of larger fluctuations than at Postojna 1 (Fig. 7). The winter arithmetic mean radon concentration $C_{\mathrm{Rn}}(\mathrm{w})=1492 \pm 1334 \mathrm{~Bq} \mathrm{~m} \mathrm{~m}^{-3}$ was calculated from the beginning of December 2006 to the end of February 2007, and the summer mean $C_{\mathrm{Rn}}(\mathrm{s})=$ $4857 \pm 1681 \mathrm{~Bq} \mathrm{~m}^{-3}$ from the beginning of July to the end of August 2007. The ratio $C_{\mathrm{Rn}}(\mathrm{w}) / C_{\mathrm{Rn}}$ (tot) $=0.39$ is much lower than, and $C_{\mathrm{Rn}}(\mathrm{s}) / C_{\mathrm{Rn}}$ (tot) $=1.26$ similar to other parts of the cave (Vaupotič, 2008). This low $C_{\mathrm{Rn}}(\mathrm{w}) /$ $C_{\mathrm{Rn}}$ (tot) value could have been caused by micro movements, as well as the chimney effect. At the beginning of the plot in Figure $8 C_{\mathrm{Rn}}$, values are high, start to decrease as 
E10a $(y)$ approaches its end, and are very low at the end of this period, although the outdoor temperature was above $10{ }^{\circ} \mathrm{C}$ and, hence, the chimney effect could not be operative. Soon after that, two $C_{\mathrm{Rn}}$ peaks appear at the temperature minima, which is contrary to expectations based on the chimney effect. $C_{\mathrm{Rn}}$ then remains constantly low till almost the end of the $\operatorname{E} 10 \mathrm{~b}(y)$ unrest. There are periods of elevated $C_{\mathrm{Rn}}$ in the second halves of November and December 2006 and January 2007, and the beginning of February 2007, again at the temperature minima as before. Because no unrest was recorded during these times, these elevated Rn levels, except for those in the second half of November 2006, may be assumed as anomalies, possibly coinciding with earthquakes on January $1,2007\left(M_{\mathrm{L}}=3.8\right.$, $\left.R / R_{\mathrm{D}}=1.9\right)$ and February 5, $2007\left(M_{\mathrm{W}}=4.5, R / R_{\mathrm{D}}=\right.$ 1.1), respectively. The November 2006 anomaly could not have been paralleled with the January 1, 2007 earthquake because the anomaly precedes the earthquake. The arithmetic means of $C_{\mathrm{Rn}}$ for the periods from October 13 to November 16, 2006 (E10a $(y)$ unrest) and from January 12 to February 16, $2007(\mathrm{E} 10 \mathrm{~b}(y)$ unrest $)$ are $C_{\mathrm{Rn}}(\mathrm{E} 10 \mathrm{a})=$ $3267 \pm 2925 \mathrm{~Bq} \mathrm{~m}^{-3}$ and $C_{\mathrm{Rn}}(\mathrm{E} 10 \mathrm{~b})=1105 \pm 1040 \mathrm{~Bq}$ $\mathrm{m}^{-3}$. If the first average is compared with the summer average and the second with the winter average, the following ratios are obtained: $C_{\mathrm{Rn}}(\mathrm{E} 10 \mathrm{a}) / C_{\mathrm{Rn}}(\mathrm{s})=0.67$ and $C_{\mathrm{Rn}}(\mathrm{E} 10 \mathrm{~b}) / C_{\mathrm{Rn}}(\mathrm{w})=0.74$. This suggests that horizontal movement (Fig. 6, E10), either dextral or sinistral, significantly reduced radon levels on the observed fault.

With the appearance of the $\mathrm{E} 11 \mathrm{a}(x)$ unrest (from February 16 to August 29, 2007; Fig. 6), $C_{\mathrm{Rn}}$ starts to increase (Figs. 8 and 9), resulting in an arithmetic mean of the entire unrest of $C_{\mathrm{Rn}}(\mathrm{E} 11 \mathrm{a})=4314 \pm 2273 \mathrm{~Bq} \mathrm{~m}^{-3}$. This value is not significantly higher than $C_{\mathrm{Rn}}($ tot $)$, the ratio $C_{\mathrm{Rn}}(\mathrm{E} 11 \mathrm{a}) / C_{\mathrm{Rn}}$ (tot) being 1.12 , and it may therefore be concluded that extension did not influence radon transport. No radon anomalies have been observed during the earthquakes occurring on May 2, $2007\left(M_{\mathrm{L}}=3.4, R /\right.$ $\left.R_{\mathrm{D}}=2.8\right)$, July $18,2007\left(M_{\mathrm{L}}=4.6, R / R_{\mathrm{D}}=2.5\right)$ or August 13, $2007\left(M_{\mathrm{L}}=4.1, R / R_{\mathrm{D}}=1.6\right)$, although their magnitudes were relatively high for the region and $R / R_{\mathrm{D}}$ values quite low (Zmazek et al., 2003).

On August 29, 2007, the E11(x) unrest continued but changed from extension to compression $(\mathrm{E} 11 \mathrm{~b}(x)$ from August 29 to October 16, 2007; Fig. 6). $C_{\mathrm{Rn}}$ started to increase, giving an arithmetic mean for this period $C_{\mathrm{Rn}}(\mathrm{E} 11 \mathrm{~b})=5184 \pm 2163 \mathrm{~Bq} \mathrm{~m}^{-3}$. When on September 19, 2007 the compression process slowed down (Fig. 6), $C_{\mathrm{Rn}}$ started to decrease and reached very low values towards the end of $\operatorname{E} 11 \mathrm{~b}(x)$. As for Postojna 1, it is not believed that this decrease coincided with earthquakes that occurred in the period September 26, 2007 to September 29,2007 because their epicenters were too far away $\left(R / R_{\mathrm{D}}\right.$ between 4.8 and 7.1), although their magnitudes were not so low for the region ( $M_{\mathrm{L}}$ from 2.1 to 3.1) (Zmazek et al., 2003). Because $C_{\mathrm{Rn}}(\mathrm{E} 11 \mathrm{~b})$ is significantly higher than $C_{\mathrm{Rn}}$ (tot), with $C_{\mathrm{Rn}}(\mathrm{E} 11 \mathrm{~b}) / C_{\mathrm{Rn}}$ (tot) $=1.35$, it can be concluded that compression significantly facilitates radon transport, thus increasing its activity in air. If only the fast compression period (from August 29 to September 19, 2007; Fig. 6) is taken into account, the related $C_{\mathrm{Rn}}$ arithmetic mean is $6150 \pm 1739 \mathrm{~Bq} \mathrm{~m}^{-3}$ and the effect of compression on radon transport is even more pronounced.

\section{Conclusions}

Recent studies of active tectonics in Slovenia (Cunningham et al., 2006; Poljak, 2007; Rižnar et al, 2007; Verbič, 2005; Vrabec and Fodor, 2006) suggest that some caves should preserve and generate traces of active tectonics. In this context, two TM 71 extensometers were installed in 2004 in Postojna Cave on the Dinaric-oriented fault zone, situated about 1,000 $\mathrm{m}$ to the north of the Predjama Fault (Fig. 1)

The measurements of tectonic micro-displacements showed small tectonic movements on both instruments, a general dextral horizontal movement of $0.05 \mathrm{~mm}$ in four years (Postojna 1, Figure 5) and an extension of $0.03 \mathrm{~mm}$ in four years (Postojna 2, Figure 6). Eleven extremes of characteristic changes in displacement were determined between variable calm periods. Contemporaneous with some stronger earthquakes (for example Krn earthquake, July $12,2004, M_{\mathrm{W}}=5.2$ ), unrest was detected. For example, movements of $0.03-0.075 \mathrm{~mm}$ were detected in the period of one month along the fault zone. However, after the earthquake, the rock generally returns to the same position as before the earthquake. Similar behavior was described in Slovakia (Briestenský et al., 2007) and other countries (Košták et al., 2007) where we were monitoring a seismic fault zone and detecting the micro-tectonic changes in Earth's crust before, during and after the earthquakes.

The greatest short-term movement was a compression of $0.04 \mathrm{~mm}$ in seven days, detected in March 2005 and coincided with the $25 \mathrm{~km}$ distant Ilirska Bistrica earthquake $\left(M_{\mathrm{L}}=3.9\right)$. About two months before the earthquake, an extension of $0.05 \mathrm{~mm}$ occurred, and one month before the earthquake the stress changed into a compression of $0.05 \mathrm{~mm}$. The largest permanent shift was detected at the end of 2004. Along the $y$-axis (at Postojna 1), a dextral horizontal movement of $0.075 \mathrm{~mm}$ was observed in one month. After the sinistral horizontal movement of $0.02 \mathrm{~mm}$ (December 15, 2004 to December 27, 2004), the $y$-axis retained its position on $0.05 \mathrm{~mm}$, where it is still today. Regarding the extremes, ten earthquakes that coincide with tectonic micro-displacements were selected. In the time frame of speleogenesis, the monitored fault zone today represents a stable cave environment.

During horizontal movement, either dextral or sinistral, radon pathways underground were partly closed, thus hindering radon migration and reducing its concentration in the cave air. Extension does not appear to have affected radon transport. Alternatively, the compression process 
(Postojna 2, February-August 2007) appears to have opened some new routes for radon transport, thus facilitating radon migration and increasing its concentration in air. In the present state of knowledge, a more solid explanation of these findings is not possible.

The comparative study is ongoing. The observed fault zone transmits only very small tectonic movements, but long-term monitoring of different parameters could sufficiently explain the relations in Earth's karst massif related to changes in stress and strain before, during, and after the stronger earthquakes. Finally, we will continue our comparative research with other monitoring sites where we have results and ongoing data collection (Stemberk et al., 2003; Košták et al., 2007; Stemberk and Košták, 2007; Briestenský et al., 2007).

\section{ACKNOWLEDGMENTS}

The authors thank Mr. Mladen Živčić (Office of Seismology of the Environmental Agency of the Republic of Slovenia) for suggesting the combined measurements of radon concentrations and micro-tectonic deformations within this study, and Mrs. Ina Cecić (the same Office) for providing the information on the earthquake in Postojna Cave from the Edinost newspaper (Anonymous, 1926). The study was part of the projects: COST 625, Slovenia-Czech Republic cooperation in science and technology (BI-CZ/06-07-011 and BI-CZ/08-09-015).

\section{REFERENCES}

Anonymous, 1926, Iz tržaške pokrajine, Postojna, sedem dni potresa: Edinost, 8.jaunar 1926, Trst.

Avramova-Tacheva, E., and Košták, B., 1995, Local three-dimensional extensiometric measurements for the determination of displacements in the Krupnik fault zone, Bulgaria: Acta Montana IRSM AS CR, series A, no. 8 (97), p. 87-98.

Bajc, J., Aoudia, A., Saraò, A., and Suhadolc, P., 2001, The 1998 BovecKrn mountain (Slovenia) earthquake sequence: Geophysical Research Letters, v. 28, no. 9, p. 1839-1842.

Bini, A., Quinif, Y., Sules, O., and Uggeri, A., 1992, Les mouvements tectoniques recents dans les grottes du Mont Campo dei Fiori (Lombardie, Italie): Karstologia, v. 19, p. 23-30.

Briestenský, M., Stemberk, J., and Petro, L., 2007, Displacements registered around the 13 March 2006 Vrbové earthquake $\mathrm{M}=3.2$ (Western Carpathians): Geologica Carpathica, v. 58, no. 5, p. 487-493.

Čar, J., and Šebela, S., 1998, Bedding planes, moved bedding planes, connective fissures and horizontal cave passages (examples from Postojnska Jama cave): Acta Carsologica, v. 27, no. 2, p. 75-95.

Cunningham, D., Grebby, S., Tansey, K., Gosar, A., and Kastelic, V., 2006, Application of airborne LiDAR to mapping seismogenic faults in forested mountainous terrain, southeastern Alps, Slovenia: Geophysical Research Letters, v. 33, L20308 p. doi:10.1029/ 2006GL027014.

Dobrovolsky, I.P., Zubkov, S.I., and Miachkin, V.I., 1979, Estimation of the zone of earthquake preparation zone: Pure and Applied. Geophysics, v. 117, p. 1025-1044.

Etiope, G., and Martinelli, G., 2001, Migration of carrier and trace gases in the geosphere: An overview: Physics of Earth Planet Interiors, v. 129 , p. $185-204$.

European-Mediterranean Seismological Center, 2008, Database of Local Seismological Bulletins from European-Mediterranean Networks: http://www.emsc-csem.org/index.php?page $=$ data\&sub $=$ base [accessed January 9, 2008].

Gilli, E., and Delange, P., 2001, Utilisation des spélèothèmes comme indicateurs de néotectonnique ou de paléosismicité: Riviera 2000, Tectonique active et géomorphologie, Villefranche-sur-Mer: Revue d'Analyse Spatial-No. Spécial 2001, p. 79-90.

Gosar, A., Šebela, S., Košták, B., and Stemberk, J., 2007, Microdeformation monitoring of active tectonic structures in W Slovenia: Acta Geodynamics et Geomaterialia, v. 4, no. 1, p. 87-98.

Kastelic, V., and Cunningham, D., 2006, Multi-disciplinary investigation of active strike-slip fault propagation in the Julian Alps: The Ravne Fault, NW Slovenia: Geophysics. Research Abstracts, v. 8, p. 05018.

Knez, M., 1996, The bedding-plane impact on development of karst caves (An example of Velika Dolina, Škocjanske Jame Caves): Ljubljana, Zbirka ZRC, no. 14, 186 p.

Kogovšek, J., and Šebela, S., 2004, Water tracing through the vadose zone above Postojnska Jama, Slovenia: Environmental Geology, v. 45, no. 7, p. $992-1001$.

Košták, B., 1969, A new device for in-situ movement detection and measurement: Experimental Mechanics 9, p. 374-379.

Košták, B., 1977, Terčové měřidlo TM-71 a jeho užití pro měření velmi pomalých pohybů na poruchách a trhlinách: Inž. Stavby, v. 25, no. 5 , p. 213-218.

Košták, B., 1991, Combined indicator using Moiré technique, in Proceedings of the. $3^{\text {rd }}$ International Symposium on Field Measurements in Geomechanics, Oslo, Balkema, p. 53-60.

Košták, B., Cacoń, S., Dobrev, N.D., Avramova-Tacheva, E., Fecker, E., Kopecký, J., Petro, L., Schweizer, R., and Nikonov, A.A., 2007, Observations of tectonic microdisplacements in Europe in relation to the Iran 1997 and Turkey 1999 earthquakes: Izvestiya - Physics of the Solid Earth, v. 43, no. 6, p. 503-516.

Márton, E., Ćosović, V., Drobne, K., and Moro, A., 2003, Palaeomagnetic evidence for Tertiary counterclockwise rotation of Adria: Tectonophysics, v. 377, p. 143-156.

Ministry for Environment and Spatial Planning, Environmental Agency of the Republic of Slovenia, 2008, Seismology: http://www.arso.gov.si/ potresi/ [accessed January 9, 2008].

Mocchiutti, A., and D'Andrea, A., 2002, Morphologic evidence of recent and modern tectonic movements in some caves of the Friuli Prealps (northeastern Italy): Memoirs of the Society of Geology Italy, v. 57, p. $487-491$

Nero, A.V., 1988, Radon and its decay products in indoor air: an overview, in Nazaroff, W.W., and Nero, Jr., A.V., eds., Radon and its Decay Products in Indoor Air, New York, John Wiley \& Sons, p. $1-53$.

Petrič, M., and Šebela, S., 2004, Vulnerability mapping in the recharge area of the Korentan spring, Slovenia: Acta Carsologica, v. 33, no. 2, p. $151-168$.

Placer, L., 1999, Structural meaning of the Sava folds: Geologija, v. 41, p. $191-221$.

Plan, L., Spötl, Ch., Grasemann, B., Decker, D., Offenbecher, K.H., and Wiesmayr, G., 2005, Seismothems caused by neotectonic activity in the Eastern Alps, in 14th International Congress of Speleology, Final Programme \& Abstract Book, p. 117-118.

Poljak, M., 2007, Structural-Tectonic Map of Slovenia 1:250.000, Ljubljana, Geological Survey of Slovenia, $52 \mathrm{p}$.

Poljak, M., Živčić, M., and Zupančič, P., 2000, The seismotectonic charateristics of Slovenia: Pure and Applied Geophysics, v. 157, p. $37-55$.

Ribarič, V., 1982, Seismicity of Slovenia - Catalogue of Earthquakes (792 A.D.-1981): Ljubljana, SZ SRS Publication Ser. A, no. 1-1, 649 p.

Rižnar, I., Koler, B., and Bavec, M., 2007, Recent activity of the regional geologic structures in western Slovenia: Geologija, v. 50, no. 1, p. $111-120$.

Sasowsky, I.D., Šebela, S., and Harbert, W., 2003, Concurrent tectonism and aquifer evolution $>100,000$ years recorded in cave sediments, Dinaric karst, Slovenia: Environmental Geology, v. 44, p. 8-13.

Šebela, S., 1998, Tectonic structure of Postojnska jama cave system: Ljubljana, Zbirka ZRC, no. 18, 112 p.

Šebela, S., 2005, Monitoring of active tectonic structures - Project COST 625: Acta Carsologica, v. 34, no. 2, p. 471-488.

Šebela, S., Slabe, T., Liu, H., and Pruner, P., 2004, Speleogenesis of selected caves beneath the Lunan Shilin and Caves of Fenglin Karst in 
Qiubei, Yunnan: Acta Geologica Sinica (English edition.), v. 78, no. 6, p. 1289-1298.

Šebela, S., Gosar, A., Košták, B., and Stemberk, J., 2005, Active tectonic structures in the $\mathrm{W}$ part of Slovenia - setting of micro-deformation monitoring net: Acta Geodynamics et Geomaterialia, v. 2, no. 1, p. 45-57.

Stemberk, J., Košták, B., and Vilimek, V., 2003, 3D monitoring of active tectonic structures: Journal of Geodynamics, v. 36, no. 1-2, p. $103-112$.

Stemberk, J., and Košták, B., 2007, 3-D trend of aseismic creep along active faults in western part of the Gulf of Corinth Greece: Acta Geodynamics Geomater, v. 4, no. 1, p. 53-65.

Vaupotič, J., 2008, Nanosize radon short-lived decay products in the air of the Postojna Cave: Science of the Total Environment, v. 393, p. $27-38$.

Vaupotič, J., Csiege, I., Radolić, V., Hunyadi, I., Planinić, J., and Kobal, I., 2001, Methodology of radon monitoring and dose estimates in Postojna Cave, Slovenia: Health Physics., v. 80, p. 142-147.

Verbič, T., 2005, Quaternary stratigraphy and neotectonics of the Eastern Krško Basin. Part 2: Neotectonics: Razprave IV, Razreda SAZU, v. 66 , no. 1, p. 171-216.

Virk, H.S., Singh, M., and Ramola, R.C., 1997, Radon monitoring for uranium exploration, earthquake prediction and environmental health hazard in Himachal Pradesh, India: an appraisal: in Virk, H.S., ed., Rare gas geochemistry - applications in earth and environmental sciences, Amristar, Guru Nanak Dev University, p. 89-99.

Vrabec, M., and Fodor, L., 2006, Late Cenozoic Tectonics of Slovenia: Structural Styles at the Northeastern Corner of the Adriatic microplate: in Pinter, N., Grenerczy, G., Weber, J., Medak, D., and Stein, S., eds., Proceedings of the NATO Advanced Research Workshop on The Adria microplate: GPS Geodesy, Tectonics, and Hazards, Veszprem, Springer, Hungary 4-7 April 2004, NATO Science Series, IV, Earth and Environmental Sciences, v. 61, p. $151-168$.

Weber, J.C., Vrabec, M., Stopar, B., and Dixon, T., 2004, New GPS constraints on Adria microplate kinematics, dynamics, and rigidity from the Istria peninsula, Slovenia and Croatia: GSA Abstracts with Programs, v. 36, no. 5

Wu, Y., Wang, W., Liu, H., Zhou, X., Wang, L., and Titus, R., 2003, Radon concentration: a tool for assessing the fracture network at Guanyinyan study area, China: Water SA, v. 29, p. 49-53.

Zmazek, B., Todorovski, L., Džeroski, S., Vaupotič, J., and Kobal, I., 2003, Application of decision trees to the analyis of soil gas radon data for earthquake predisction: Applied Radiation Isotopes, v. 58, p. 697-706. 